\title{
An improved method for the diagnosis of polycythaemia
}

\author{
D. P. BENTley, W. H. THOMSON, AND J. A. F. NAPIER
}

From the Department of Haematology and Medical Physics, University Hospital of Wales, Heath Park, Cardiff, UK

SUMMARY The red cell mass was measured in 44 normal subjects and showed a closer correlation with total body water or surface area than with body weight. The results obtained in a group of patients with polycythaemia, however, still overlap with the normal range. When the total number of circulating red cells is measured these patients form a group quite separate from the normals. The diagnostic value of this measurement is therefore considerably greater than results obtained with the red cell mass.

The diagnosis of polycythaemia, whatever the cause, depends upon the measurement of the red cell mass (RCM) (Berlin, 1975) using an isotope dilution technique. The International Committee for Standardisation in Haematology (ICSH, 1973) has recommended that the RCM should be expressed as millilitres of red cells per kilogram body weight. However, the range for normals is wide, and there is a marked difference between the values obiained for males and for females. Results expressed in this way may be particularly misleading in obese subjects because of the relatively avascular nature of adipose tissue. Attempts have been made to minimise these differences by relating red cell mass to total body water or surface area (Retzlaff et al., 1969), and this has greatly reduced the errors due to obesity.

In polycythaemia, an increase in the number of circulating red cells leads to a rise in the haemoglobin concentration and the haematocrit of venous blood. The present study was undertaken to determine whether abnormal erythroid proliferation may be better demonstrated by determination of the total number of circulating red cells rather than the red cell mass.

\section{Subjects and methods}

Forty-four healthy adult volunteers (24 men and 20 women), including three obese subjects, were studied. The range of haemoglobin concentration was 14.0$17.5 \mathrm{~g} / \mathrm{dl}$ for the men and $11 \cdot 1-15 \cdot 5 \mathrm{~g} / \mathrm{dl}$ for the women, and of haematocrit $\mathbf{0} \cdot 389-0 \cdot 505$ for the men

Received for publication 15 March 1978 and $0 \cdot 370-0 \cdot 455$ for the women. Thirteen patients with polycythaemia were investigated. The diagnosis was based upon clinical observations (high complexion, pruritus, splenomegaly) and examination of the peripheral blood (elevated haemoglobin concentration, haematocrit or red cell count, leucocytosis, basophilia, etc). The range of haemoglobin concentration was $14 \cdot 3-20.8 \mathrm{~g} / \mathrm{dl}$ for the men and $14 \cdot 2-25.9 \mathrm{~g} / \mathrm{dl}$ for the women. Haematocrit was in the range $0.445-0.617$ for the men and 0.437 0.779 for the women. Patients in whom there was evidence of iron deficiency were not excluded.

Haemoglobin concentration and red cell count (RBC) were measured using a Coulter $\mathrm{S}$ automatic cell counter. The haematocrit (Hct) was calculated from the mean corpuscular volume and the RBC with the exclusion of trapped plasma.

Autologous red cells were labelled with $25 \mu \mathrm{Ci}$ $99 \mathrm{~m}$ Tc by the method of Eckelman et al. (1971), or with $25 \mu \mathrm{Ci}{ }^{51} \mathrm{Cr}$. The activity of the labelled cells was measured before injection, and of a 4-ml sample of whole blood taken 15 minutes after injection, or after 60 minutes in those patients with palpable enlargement of the spleen, in whom cells were always labelled with ${ }^{51} \mathrm{Cr}$.

Total circulating red cell count (TRBC) was calculated thus:

\begin{tabular}{|c|c|}
\hline \multicolumn{2}{|r|}{ Activity iniected } \\
\hline TRBC $=$ & Activity par ml blood after mixing is \\
\hline
\end{tabular}
where $\mathrm{RBC}$ is the number of cells per litre of blood. Red cell mass (RCM) was calculated thus: 


$$
\mathrm{RCM}=\frac{\text { Activity injected }}{\text { Activity per } \begin{array}{c}
\mathrm{ml} \text { blood after mixing is } \\
\text { completed }
\end{array}}
$$

Total body water (TBW) was measured using $200 \mu \mathrm{Ci}$ tritiated water, as outlined by Preece $e t$ al . (1975).

Body surface area (SA) was determined from the subject's height and weight using the equation derived by DuBois and DuBois (1916).

\section{Results}

The relationship of RCM to the subject's body weight for the normal volunteers, including the three obese women, is shown in Figure 1. The values in the latter are well separated from those for the non-obese subjects. For the same subjects, the relationship of RCM to TBW is shown in Fig. 2, and it can be seen that the obese subjects no longer form a separate group. A similar improvement can be demonstrated using surface area instead of TBW as the reference parameter. Furthermore, the relationship of TRBC to surface area and to TBW in the normal subjects is comparable to that obtained using RCM.

The values of RCM and TBW obtained in 13 polycythaemic subjects are shown in Figure 3. The regression line and $95 \%$ prediction interval for the normal subjects are shown. It can be seen that

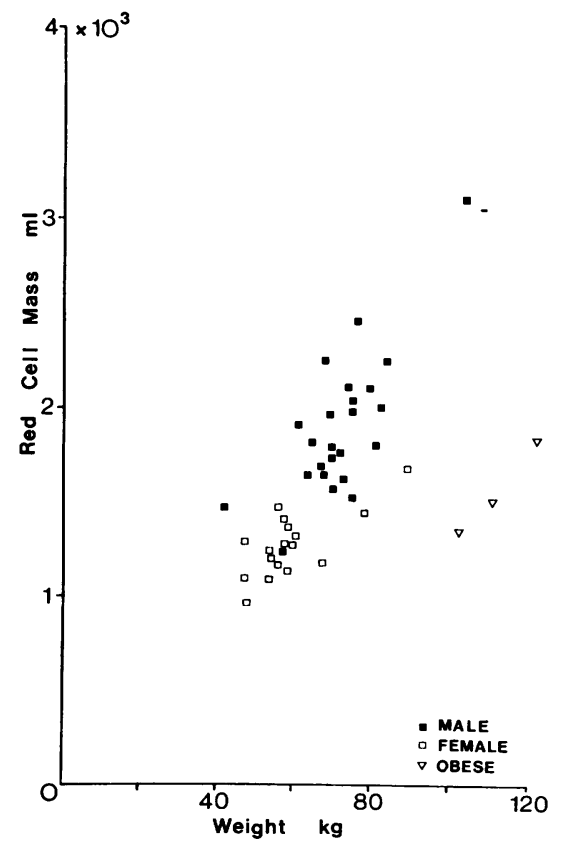

Fig. 1 Relationship of red cell mass to body weight in the normal subjects (including three obese women).

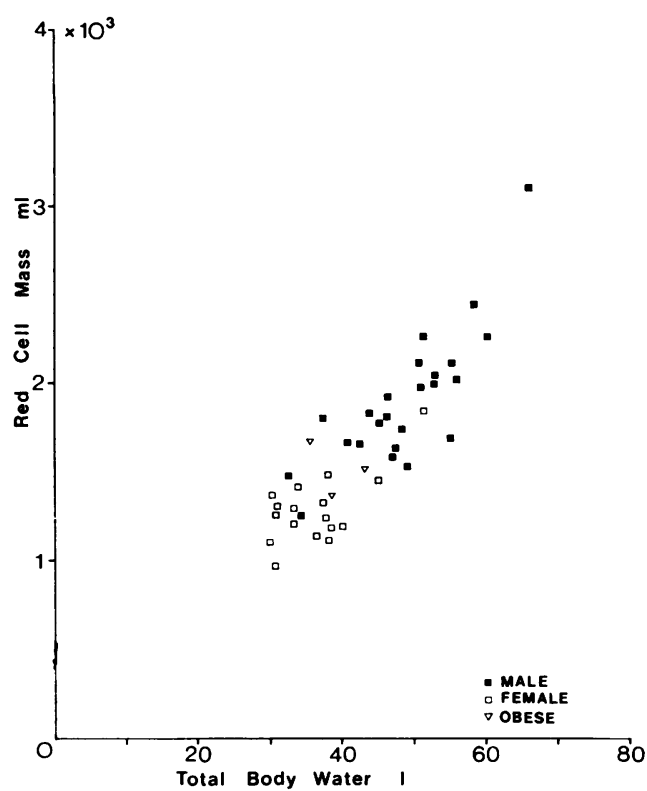

Fig. 2 Relationship of red cell mass to total body water in the normal subjects (including three obese women).

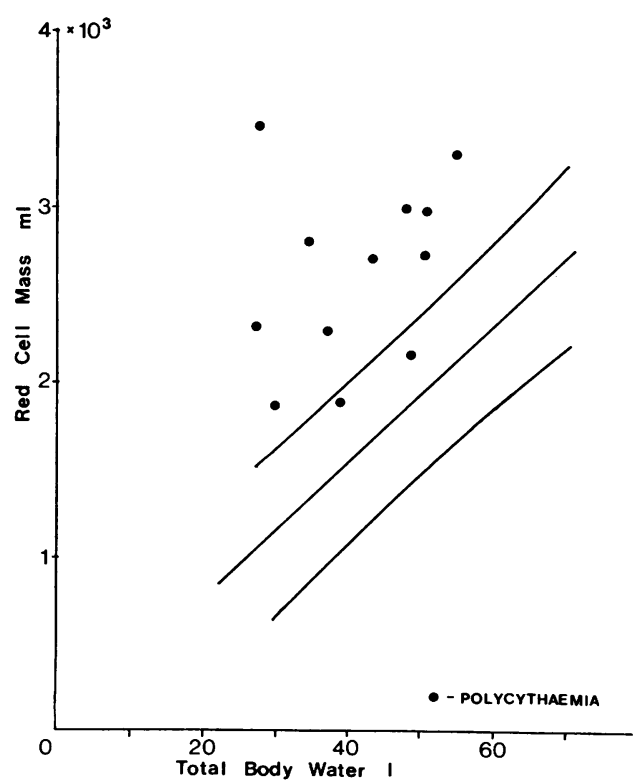

Fig. 3 Red cell mass and total body water for 13 polycythaemic patients. Regression line $(R C M=40 \cdot 26$ TBW $-89.6 ; r=0.867)$ for normals shown, together with $95 \%$ tolerance limits. 


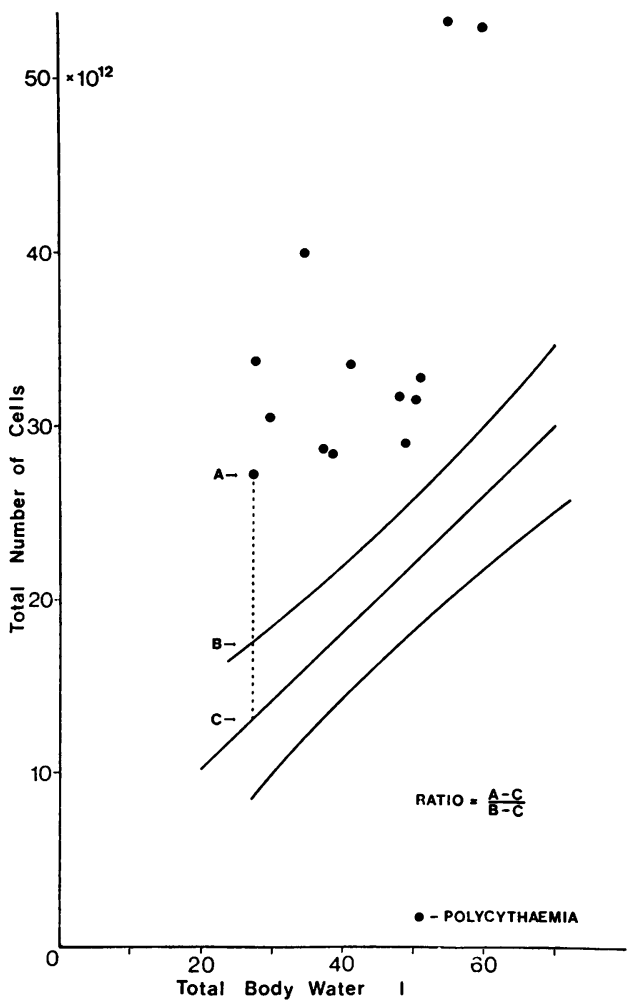

Fig. 4 Total red cell count and total body water for 13 polycythaemic patients. Regression line (TRBC $=0.395$ $T B W+2.005 ; r=0.874$ ) for normals shown, together with $95 \%$ tolerance limits.

two of the polycythaemic patients fall within the normal limits. For the same patients, the TRBC and TBW are shown in Fig. 4, together with regression line and $95 \%$ prediction interval for the normal group. It can be seen that all the patient values now lie outside the normal limits. Similar results are obtained using surface area instead of TBW as the reference parameter.

\section{ANALYSIS OF RESULTS}

To compare the various correlations in the polycythaemic patients, the following ratio was calculated (see Fig. 4). For each patient the predicted normal value of TRBC was obtained from the equation of the regression line. This is denoted by $\mathrm{C}$ in Fig. 4 for the patient shown with value $A$. The corresponding value $(B)$ of the prediction interval was also obtained.

The ratio $\frac{A-C}{B-C}$ was calculated for each polycythaemic patient relating $R C M$ and TRBC to TBW and to SA. When this ratio has a value of less than unity the results are considered to fall within the normal range.

Table Mean and range of the ratio $\frac{A-C}{B-C}$ (see text) for the polycythaemic patients

\begin{tabular}{lll}
\hline Relationship & Mean & Range \\
\hline $\begin{array}{l}\text { Red cell mass } \\
\text { related to surface area }\end{array}$ & $2 \cdot 30$ & $0 \cdot 67-5 \cdot 00$ \\
$\begin{array}{l}\text { Red cell mass } \\
\text { related to total body water }\end{array}$ & $2 \cdot 53$ & $0 \cdot 64-5 \cdot 20$ \\
$\begin{array}{l}\text { Total red cell count } \\
\text { related to surface area }\end{array}$ & 3.45 & $1 \cdot 82-6 \cdot 37$ \\
$\begin{array}{l}\text { Total red cell count } \\
\text { related to total body water }\end{array}$ & 3.45 & $1 \cdot 72-6.52$ \\
\hline
\end{tabular}

The Table gives the mean and range of values for the ratio in the polycythaemic patients using each relationship. It can be seen that, using TRBC with either TBW or SA, the mean value of the ratio is greater than that obtained using RCM. This difference is significant $(P<0.005)$. There is no significant difference $(P>0 \cdot 1)$ between the ratio values obtained using total body water or surface area as the reference parameter.

\section{Discussion}

Measurement of the red cell mass is an essential step in the evaluation of patients thought to have polycythaemia. The definition of the normal range has, however, caused some difficulty, and no ideal means of expressing results has been devised. Relating red cell mass to body weight, as recommended by the ICSH, has the advantage of simplicity, but adipose tissue is relatively avascular, and the use of a parameter related to lean body mass is probably more appropriate. Wennesland et al. (1959), Brown et al. (1962), and Retzlaff et al. (1969) have found a better correlation between red cell mass and a combined formula of height and weight than with weight alone. Retzlaff et al. (1969) demonstrated a similar improvement when TBW was used. In the present study, the correlation of red cell mass with surface area was comparable to that with total body water. In either instance the most striking improvement was with respect to the three obese subjects, whose results then fell within the range found for the non-obese.

The diagnosis of polycythaemia often depends on an arbitrary decision upon whether the red cell mass is normal or increased. It has been shown in the present study that when red cell mass was expressed in millilitres and related to surface area or total body water, two of the patients, in whom a diagnosis of polycythaemia was made on other criteria, fell within the normal range. Calculation of the total 
number of circulating red cells permitted clear separation of the patients from the normal subjects. The greater diagnostic value of TRBC may be due to the relative iron deficiency found in many patients with polycythaemia (Kurnick et al., 1972). This limits haemoglobin synthesis and the haematocrit while having less effect on the number of circulating red cells. It is suggested that by using the total red cell number rather than red cell mass, and relating this to body surface area, a diagnosis of polycythaemia can be established or refuted with greater confidence than has previously been possible. The total red cell number is calculated as shown in equation 1 and requires no physical procedure other than those normally carried out. Derivation of a ratio from the predicted normal value for a subject simplifies interpretation of the results.

We thank Mr. D. Trevett and Mr R. D. Bishop for technical assistance.

\section{References}

Berlin, N. I. (1975). Diagnosis and classification of the polycythaemias. Seminars in Haematology, 12, 339-351.

Brown, E., Hopper, J., Jr., Hodges, J. L., Jr., Bradley, B., Wennesland, R., and Yamauchi, H. (1962). Red cell, plasma, and blood volume in healthy women measured by radio-chromium cell labeling and hematocrit. Journal of Clinical Investigation, 41, 21822190.

DuBois, D., and DuBois, E. F. (1916). A formula to estimate the approximate surface area if height and weight be known. Archives of Internal Medicine, 17, 863-964.

Eckelman, W., Richards, P., Hauser, W., and Atkins, H. (1971). Technetium-labeled red blood cells. Journal of Nuclear Medicine, 12, 22-24.

International Committee for Standardisation in Haematology (1973). Standard techniques for the measurement of red-cell and plasma volume. British Journal of Haematology, 25, 801-814.

Kurnick, J. E., Ward, H. P., and Block, M. H. (1972). Bone marrow sections in the differential diagnosis of polycythemia. Archives of Pathology, 94, 489-499.

Preece, P. E., Richards, A. R., Owen, G. M., and Hughes, L. E. (1975). Mastalgia and total body water. British Medical Journal, 4, 498-500.

Retzlaff, J. A., Tauxe, W. N., Kiely, J. M., and Stroebel, C. F. (1969). Erythrocyte volume, plasma volume, and lean body mass in adult men and women. Blood, 33, 649-667.

Wennesland, R., Brown, E., Hopper, J., Jr., Hodges, J. L., Jr., Guttentag, O. E., Scott, K. G., Tucker, I. N., and Bradley, B. (1959). Red cell, plasma and blood volume in healthy men measured by radiochromium $\left(\mathrm{Cr}^{51}\right)$ cell tagging and hematocrit. Influence of age, somatotype and habits of physical activity on the variance after regression of volumes to height and weight combined. Journal of Clinical Investigation, 38, 1065-1077.

Requests for reprints to: Dr D. P. Bentley, Department of Haematology, University Hospital of Wales, Heath Park, Cardiff CF4 4XW, UK. 